\title{
Fruit and vegetable consumption among the young Polish population
}

\section{Spożywanie warzyw i owoców w populacji młodych Polaków}

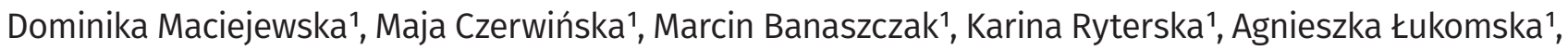 \\ Sandra Budrewicz², Magdalena Skowronek2 ${ }^{2}$ Adam Stachowski ${ }^{3}$ Ewa Stachowska ${ }^{1 凶}$
}

1 Pomorski Uniwersytet Medyczny w Szczecinie, Zakład Biochemii i Żywienia Człowieka, ul. Broniewskiego 24, 71-460 Szczecin

${ }^{2}$ Absolwentka Wydziału Nauk o Zdrowiu Pomorskiego Uniwersytetu Medycznego w Szczecinie, ul. Żołnierska 48, 71-210 Szczecin

${ }^{3}$ Student Wydziału Lekarskiego Uniwersytetu Medycznego im. Karola Marcinkowskiego w Poznaniu, ul. Fredry 10, 61-701 Poznań

$\bowtie$ ewa.stachowska@pum.edu.pl

\begin{abstract}
Introduction: Vegetables and fruit are an essential part of a healthy and balanced diet. It has been shown that regular consumption of fruit and vegetables can reduce the risk of chronic diseases. However, in the past 8 years fruit and vegetable consumption among Polish youth has significantly decreased.

Materials and methods: Patients involved in the project were participants of the Woodstock Festival Poland 2014. During three days of the festival, 615 young adults (18-35 years) were enrolled in the study. The study participants had to fill in a questionnaire that included questions about the frequency of fruit and vegetable consumption, portion sizes, and knowledge of the recommended daily intake. We also measured basic anthropometric parameters. Results: The data from our study showed that $97.6 \%$ of respondents consumed fewer than 4 servings of vegetables and fruit.
\end{abstract}

In addition $39 \%$ of them ate 2 or fewer vegetable servings per day. We found that men ate significantly less fruit and fewer vegetables than women ( $p<0.05)$. Additionally, almost $75 \%$ of men responded that proper consumption of fruit and vegetables should be at the level of $2-3$ servings, and only $22.3 \%$ of them said that the proper level is $4-5$ servings.

Conclusions: We need to keep in mind that only clear information about vegetables and fruit, as well as highlighting the importance of the principles of nutrition, can give effective results in the future. It also appears that nutritional education should be conducted not only at the early stages of development but also in adolescents.

Keywords: fruit intake; vegetables intake; nutrition; Polish population; young people.

\begin{abstract}
ABSTRAKT
Wstęp: Warzywa i owoce są niezbędnym elementem zdrowej i zbilansowanej diety. Wykazano, że regularne spożywanie warzyw i owoców może zmniejszyć ryzyko wielu chorób cywilizacyjnych. Niestety, w ciągu ostatnich 8 lat spożycie owoców i warzyw wśród polskiej młodzieży znacznie spadło.

Materiały i metody: W badaniu wzięło udział 615 młodych Polaków (18-35 lat), którzy byli uczestnikami Festiwalu Woodstock 2014. Wszyscy pacjenci wypełnili kwestionariusz, który obejmował pytania dotyczące częstotliwości spożycia owoców i warzyw, wielkości porcji, a także wiedzy na temat zalecanego dziennego spożycia tych produktów żywnościowych. U każdego uczestnika zostały zmierzone podstawowe parametry antropometrczne. Wyniki: Badanie wykazało, że 97,6\% respondentów spożywa mniej niż 4 porcje warzyw i owoców. Ponadto, aż 39\% spożywa
\end{abstract}

2 lub mniej porcji warzyw dziennie. Mężczyźni spożywali znacząco mniej warzyw i owoców niż kobiety $(\mathrm{p}<0,05)$. Prawie 75\% mężczyzn uważa, że odpowiednie spożycie owoców i warzyw powinno być na poziomie 2-3 porcji dziennie, a tylko $22,3 \%$ z nich odpowiedziało, że odpowiedni poziom to $4-5$ porcji dziennie.

Wnioski: Edukacja żywieniowa jest istotnym elementem walki z chorobami cywilizacyjnymi. Należy jasno podkreślić potrzebę spożywania odpowiedniej ilości warzyw i owoców z wyraźnym zaznaczeniem odpowiednich proporcji między nimi. Wykazano również, że edukacja żywieniowa powinna być skierowana nie tylko do dzieci, ale również do młodzieży.

Słowa kluczowe: spożywanie owoców; spożywanie warzyw; żywienie; populacja polska, młodzież.

\section{INTRODUCTION}

Vegetables and fruit are an essential part of a healthy and well balanced diet. Increased consumption of vegetables and fruit is the key to chronic disease prevention [1]. They are a source of antioxidants, vitamins, polyphenols, fibre and other biologically active substances. Cardiovascular disease and cancer are major causes of death worldwide [1,2]. It has been shown that regular consumption of fruit and vegetables can reduce the risk of these diseases [3]. The therapeutic effects can be caused by

the fact that they are rich in important nutrients, e.g. minerals, macro and micronutrients and fibre, which are essential for proper body functions [4]. The minimum dose of fruit and vegetable consumption is considered to be 5 servings, or about 400 grammes per day [5]. The consumption of fruit and vegetables is very important for all body systems. There is a strong correlation between fruit and vegetables intake and reduced levels of inflammatory mediators [6]. Researchers tested the levels of: lymphocytes T, cytokines, antioxidant status, the concentration of carotenoids and vitamin $\mathrm{C}$ at the beginning 
of study, after 35 days, and 11 weeks after the intake of fruit and vegetable extracts. It was found that the study group had significantly higher levels of vitamin $\mathrm{C}$, beta-carotene, lycopene, and lutein compared to the control group. In addition, the study group had better antioxidant status, $30 \%$ increase in circulation levels of T cells and 40\% lower lymphocyte DNA damage [7]. These studies confirm the importance of the participation of fruit and vegetables in a balanced diet thanks to their preventive effects on population diseases.

What about proper nutrition awareness among young people? According to the latest nutritional standards from the Polish Institute of Food and Nutrition, vegetables and fruit should be consumed several times a day, and they should be included in the main meals and healthy snacks. One portion of vegetables and fruit can be included in fresh products, frozen products and juice. It should be noted that fruit contains more monosaccharides than vegetables, so a larger part of the diet should provide more vegetables than fruit, which also includes juice [8]. An international team of scientists carried out a metaanalysis of trends in vegetable and fruit consumption among young people in 33 countries in 2002-2010. The results for Polish youth, unfortunately, are not promising. Within these 8 years, the amount of consumed fruit and vegetables significantly decreased $(p<0.01)$ [9]. The next study, conducted by the Polish team of researchers, examined eating habits among students of the Medical University of Silesia. It was found that only $29 \%$ of the respondents consumed vegetables or fruit every day [10]. Another study shows that among Italian students only $44 \%$ ate at least one serving of fruit each day, while only $22.5 \%$ of students consumed vegetables 2 times a day [11]. Similar research conducted among Warsaw students showed that they more often chose fruit than vegetables [12].

The aim of our study was to investigate the fruit and vegetable eating habits among young participants of the Woodstock Festival Poland.

\section{MATERIALS AND METHODS}

\section{Respondents}

Respondents involved in the project were participants of the Woodstock Festival Poland (31.07-2.08.2014, Kostrzyn nad Odrą, Poland). During 3 days of the festival, 615 (307 women and 308 men) young adults (18-35 years) were enrolled in the study. The festival is free of charge, and therefore participants had various social statuses. Study participants had to fill in a questionnaire that included questions about fruit and vegetable intake, portion sizes, and knowledge of the recommended daily intake of fruit and vegetables. The respondents came from different parts of the country, including all 16 provinces of Poland. A signed informed consent form was obtained from each participant.

\section{Questionnaire}

The Questionnaire included questions about personal data, place of residence, educational status, economic status, eating
TABLE 1. Socio-economic status

\begin{tabular}{lccc}
\multicolumn{1}{c}{ Parameters } & $\begin{array}{c}\text { All } \\
\text { respondents } \\
\%\end{array}$ & $\begin{array}{c}\text { Women } \\
(\mathbf{n = 3 0 7 )} \\
\%\end{array}$ & $\begin{array}{c}\text { Men } \\
(\mathbf{n}=306) \\
\%\end{array}$ \\
\hline Place of residence: & & & \\
\hline $\begin{array}{l}\text { village } \\
\text { city <50,000 residents }\end{array}$ & 13.7 & 14 & 13.07 \\
city - 50,000-200,000 & 26 & 20.2 & 31 \\
residents & 18.2 & 19.9 & 16.67 \\
city >200.000 residents & 42.1 & 45.9 & 39.26 \\
\hline $\begin{array}{l}\text { Education: } \\
\text { basic education }\end{array}$ & 13.74 & 8.2 & 9.2 \\
secondary education & 44.06 & 51.8 & 55.4 \\
higher education & 42.2 & 40 & 35.4 \\
\hline Economic status: & & & \\
high & 50.16 & 47.54 & 52.61 \\
upper middle & 42.14 & 43.93 & 39.9 \\
lower middle & 5.24 & 4.92 & 5.86 \\
poor & 2.3 & 3.61 & 1.31 \\
very poor & 0.16 & 0 & 0.32 \\
\hline
\end{tabular}

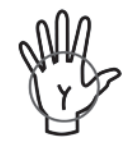

Palm size

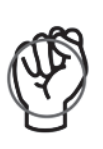

Fist size

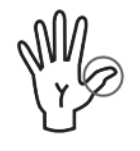

Thumb size

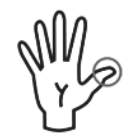

Half-thumb size
FIGURE 1. Portion sizes image shown as part of the human hand

habits, alcohol intake and smoking (Table 1). The answers to the questions related to diet were based mostly on the image of portion sizes as part of the human hand (Fig. 1).

\section{Anthropometric measurements}

Anthropometric parameters were analyzed as follows: weight (medical weight, Radwag WPT 100/200 OW), body height (medical weight, Radwag WPT model 100/200 OW). The circumference of the arm, waist and hip were measured with anthropometric tape. The skinfold thickness on triceps was measured with an anthropometric compass. Body mass index (BMI) and waist to hip ratio (WHR) were calculated according to the formula: BMI = body weight $(\mathrm{kg}) /$ height $\left(\mathrm{m}^{2}\right)$, WHR = waist circumference/hip circumference. The characteristics of the study group are shown in table 2 .

\section{Statistical analysis}

Statistica 7.1 software was used for the statistical analysis, and all results were expressed as mean \pm standard deviation (SD). As the distribution in most cases was normal (Shapiro-Wilk test), parametric tests were used - t test for comparisons between groups. Spearman's correlation test was used to calculate the association between data; $\mathrm{p}<0.05$ was considered statistically significant.

\section{RESULTS}

We analysed the study group together and divided them into men and women to present the differences between sexes. All 
TABLE 2. Anthropometric parameters

\begin{tabular}{|c|c|c|c|c|c|c|}
\hline \multirow[t]{2}{*}{ Parameters } & \multicolumn{2}{|c|}{$\begin{array}{c}\text { All respondents } \\
\%\end{array}$} & \multicolumn{2}{|c|}{$\begin{array}{c}\text { Women }(n=307) \\
\%\end{array}$} & \multicolumn{2}{|c|}{$\begin{array}{c}\text { Men }(n=306) \\
\%\end{array}$} \\
\hline & mean & SD & mean & SD & mean & SD \\
\hline Age (years) & 6.56 & 24.46 & 23 & 2.06 & 25 & 8.09 \\
\hline Height (m) & 1.72 & 0.03 & 1.69 & 0.04 & 1.73 & 0.04 \\
\hline Weight (kg) & 70.75 & 5.45 & 65.75 & 7.85 & 81.57 & 13.42 \\
\hline BMI & 23.67 & 0.78 & 23.18 & 3.84 & 27.38 & 5.87 \\
\hline Waist circumference $(\mathrm{cm})$ & 81.59 & 4.5 & 75 & 6 & 94 & 20 \\
\hline Hip circumference $(\mathrm{cm})$ & 96.77 & 1 & 96.5 & 3.5 & 102 & 5 \\
\hline WHR & 0.84 & 0.05 & 0.77 & 0.03 & 0.91 & 0.15 \\
\hline Triceps skin-fold thickness (cm) & 18.19 & 2 & 15.5 & 1.5 & 29.5 & 5.5 \\
\hline Mid-arm circumference $(\mathrm{cm})$ & 29.49 & 1.5 & 19 & 6 & 35 & 4 \\
\hline
\end{tabular}

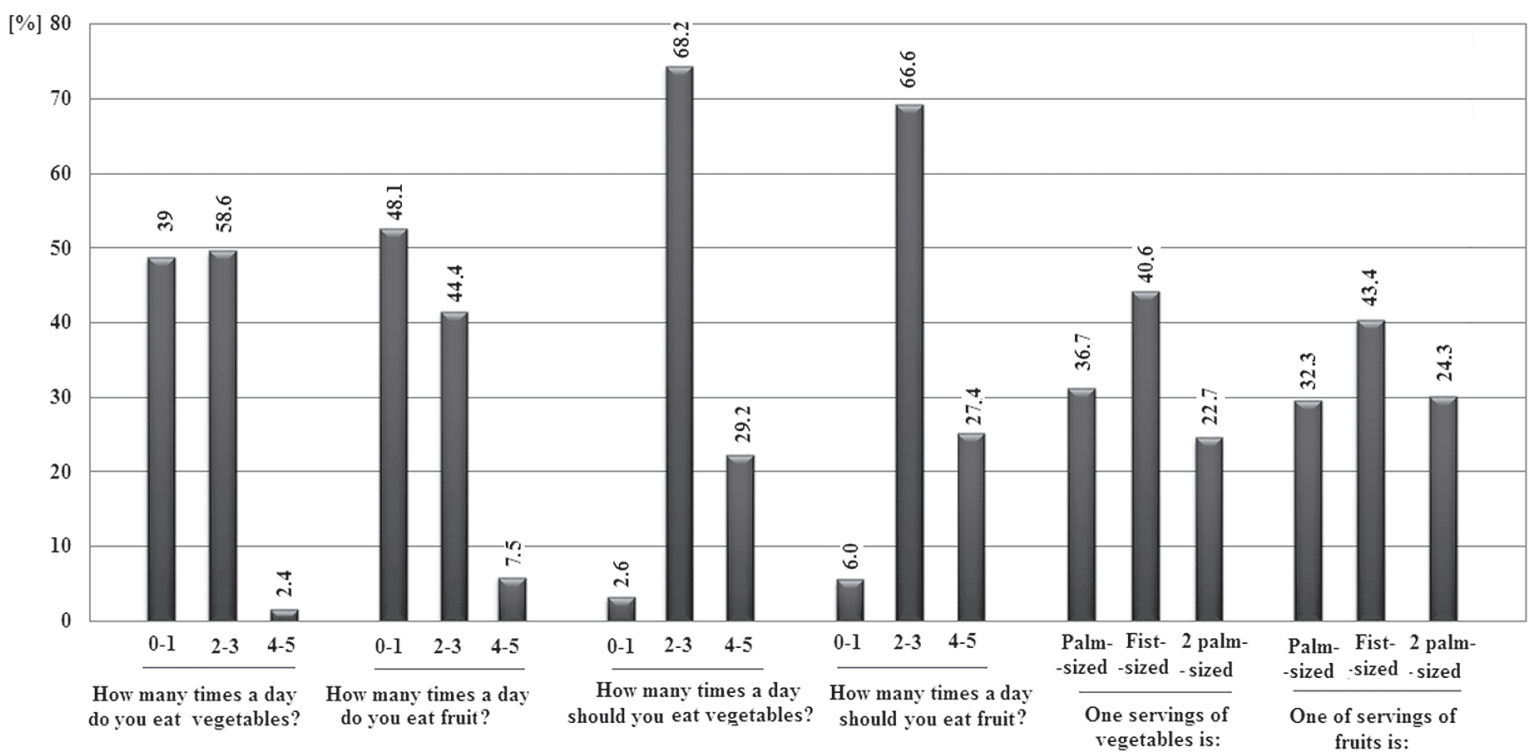

FIGURE 2. Answers of all respondents $(n=615)$

respondents filled in questionnaires about their eating habits and eating knowledge. The percentile results of their answers are shown in Figure 2. We found significant differences between men's and women's answers, which are presented in Figure 3. There were significant correlations between particular answers among our respondents. The results of the correlation are shown in Table 3.

\section{DISCUSSION}

Regular meals rich in fruit and vegetables are sufficient to cover the essential nutritional needs, like vitamins, micro- and macronutrients and electrolytes $[5,12,13,14,15,16]$. The Polish Institute of Food and Nutrition recommends a daily intake of 400 grammes of fruit and vegetables, which should be served in 5 portions. Recent recommendations point out that the recommended 5 servings are the minimum of fruit and vegetables, and the optimum amount of vegetables and fruit is 7 servings a day. One serving is an amount of vegetables and/or fruit the size of a fist, approx. $100 \mathrm{~g}$ [4]. However, $97.6 \%$ of respondents consumed fewer than 4 servings of vegetables and fruit, which is insufficient. In addition, 39\% of them ate one or fewer vegetables per day (Fig. 2). We can also see that men eat less fruit and vegetables than women ( $p<0.05$, Fig. 3). Additionally, almost $75 \%$ of men think that the consumption of fruit and vegetables should be at the level of 2-3 servings, and only $22.3 \%$ of them said that the proper level is 4-5 servings. In comparison, $36 \%$ of women answered that the proper level is $4-5$ servings. The results show that nutritional awareness among young Polish people is not at a proper level. They should be better informed about the need to eat fruit and vegetables. It is very important to increase the coverage and effectiveness of nutritional education, especially of that which is aimed at young audiences.

Nutritional education is already implemented at the early stages of children's life to develop the habit of regular consumption of fruit and vegetables. Other results confirm that properly conducted nutritional education is effective and can help to improve healthy nutrition $[17,18,19,20,21]$. Therefore, there is a growing social campaign to promote the consumption of fruit and vegetables. The most important campaigns in Poland are: " 5 portions of fruit and vegetables or juice" and 


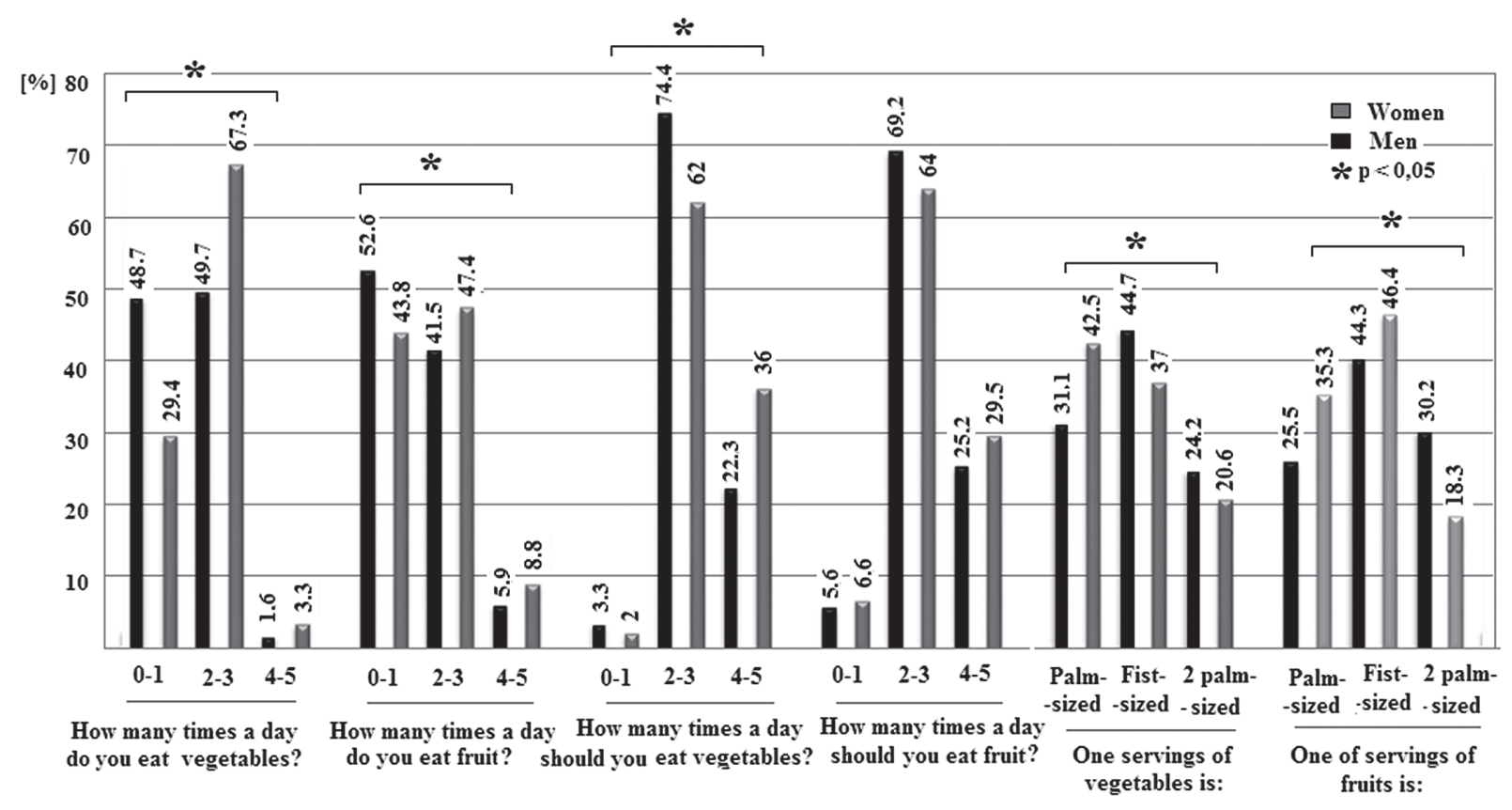

FIGURE 3. Answers of men $(n=308)$ and women $(n=307)$

TABLE 3. Correlations

\begin{tabular}{|c|c|c|c|c|c|c|}
\hline \multirow{2}{*}{ Compared parameters } & \multicolumn{2}{|c|}{ All respondents } & \multicolumn{2}{|c|}{ Women } & \multicolumn{2}{|c|}{ Men } \\
\hline & RHO & $p$ & RHO & $p$ & RHO & $\mathrm{p}$ \\
\hline Frequency of daily fruits intake vs frequency of daily vegetables intake & 0.35 & $<0.01$ & 0.34 & $<0.01$ & 0.34 & $<0.01$ \\
\hline $\begin{array}{l}\text { Knowledge of frequency of daily fruits intake vs knowledge of frequency of daily } \\
\text { vegetables intake }\end{array}$ & 0.44 & $<0.01$ & 0.42 & $<0.01$ & 0.45 & $<0.04$ \\
\hline Portion size of vegetable vs portion size of fruits & 0.37 & $<0.01$ & 0.36 & $<0.01$ & 0.36 & $<0.01$ \\
\hline $\begin{array}{l}\text { Knowledge of frequency of daily vegetables intake vs frequency of daily vegetables } \\
\text { intake }\end{array}$ & \multicolumn{2}{|c|}{ NS } & \multicolumn{2}{|c|}{ NS } & 0.3 & $<0.02$ \\
\hline Knowledge of frequency of daily fruits intake vs frequency of daily fruits intake & \multicolumn{2}{|c|}{ NS } & \multicolumn{2}{|c|}{ NS } & 0.3 & $<0.03$ \\
\hline
\end{tabular}

RHO - correlation coefficient

"Time for a tomato" [22]. However, future results can be measured in 5 to 10 years.

The results of our study may indicate that the campaigns conducted so far, as well as nutritional education in schools, have not given fully satisfactory results. Another interesting fact is that the majority of respondents ate both vegetables and fruit at the level of 2-3 servings per day. Additionally, regardless of sex, we see a significant, positive correlation (RHO $=0.35 ; \mathrm{p}<0.01$ ) between the level of consumption of fruit and vegetables. This means that the more vegetables were consumed, the more fruit was eaten. The study also shows that approximately $30 \%$ of respondents, regardless of gender, believed that vegetables and fruit should be consumed in 4-5 servings a day. We can find a positive, significant correlation between these 2 answers ( $\mathrm{RHO}=0.44 ; \mathrm{p}<0.04)$. This may suggest that the study participants saw fruit and vegetables as one group of food products. Perhaps this is due to poor knowledge about nutrition. The above-mentioned social campaigns focused mainly on the message that healthy nutrition requires 5 servings of fruit and vegetables per day. These projects do not include details, such us how many portions should come from vegetables and how many from fruit. We need to remember that both vegetables and fruit are included in the value group of healthy foods. However, vegetables contain less simple sugar, especially fructose, and should be more common in our diet than fruit. The insufficient knowledge about nutrition among the study group may be caused not only by poor education, but primarily by their own habits and food choices. We also need to remember that this is a group of young people who in the future will be parents, and as parents, they will largely shape the eating habits of their children and future generations. We see a great need for effective nutritional education in this group of young people.

It is well known that both vegetables and fruit are a valuable source of vitamins and minerals necessary for the proper functioning of the body $[23,24,25,26]$. As already mentioned, the Polish Institute of Food and Nutrition recommends eating 5 servings of vegetables and fruit, and fruit should be in the amount of maximum 2 servings per day. It is permissible to replace portions of fruit with vegetables but never the opposite [4]. Fruits have more calories than vegetables and they are richer in simple sugars. Simple sugars, like glucose and 
fructose, have a high glycaemic index and stimulate intensive insulin bursts. Despite the fact that fructose is less absorbable than glucose and has a lower glycaemic index, the daily recommended intake is reduced compared to glucose. The reasons are that fructose metabolism is faster than glucose due to the limitation of the phosphofructokinase step. Furthermore, the fructose receptors are located mainly on liver cells, which allows for the intensification of lipogenesis and triacylglycerol production. This process is more intense than in the case of glucose. Many studies indicate a strong correlation between dyslipidemia, overweight state, obesity, nonalcoholic fatty liver disease, cardiovascular disease and fructose consumption [27]. On the other hand, fruit and vegetables are sources of fibre. Insoluble fibre, which contains cellulose, hemicellulose, lignin, and resistant starch has a big impact on the regulation of bowel motility and increasing the faecal mass. Soluble fibre, thanks to its consistency, binds toxins and part of lipid compounds, and removes them from the intestines. This mechanism also helps maintain the proper level of LDL-cholesterol and triacylglycerols, which are very important in cardiovascular disease prevention [28].

\section{CONCLUSIONS}

Nutritional education should pay attention to the benefits of eating vegetables and fruit, and show the proper daily recommendations for each food group. We need to keep in mind that only clear information about vegetables and fruit, as well as highlighting the importance of the principles of nutrition can give effective results in the future. It also appears that nutritional education should be conducted not only at the early stages of development but also in adolescents.

\section{REFERENCES}

1. Wang X, Ouyang Y, Liu J, Zhu M, Zhao G, Bao W, et al. Fruit and vegetable consumption and mortality from all causes, cardiovascular disease, and cancer: systematic review and dose-response meta-analysis of prospective cohort studies. BMJ 2014;29:349.

2. Liu RH. Health benefits of fruit and vegetables are from additive and synergistic combinations of phytochemicals. Am J Clin Nutr 2003;78(3):517-20.

3. Mirmiran P, Noori N, Zavareh MB, Azizi F. Fruit and vegetable consumption and risk factors for cardiovascular disease. Metabolism 2009;58(4):460-8.

4. Jarosz M, editor. Normy żywienia dla populacji polskiej - nowelizacja. Warszawa: POL-HEALTH. Instytut Żywności i Żywienia; 2012.

5. Darmon N, Darmon M, Maillot M, Drewnowski A. Nutrient density standard for vegetables and fruits: nutrients per calorie and nutrients per unit cost. J Am Diet Assoc 2005;105(12):1881-7.

6. Lhakhang P, Godinho C, Knoll N, Schwarzer R. A brief intervention increases fruit and vegetable intake. A comparison of two intervention sequences. Appetite 2014;82:103-10.

7. Lamprecht M, Oettl K, Schwaberger G, Hofmann P, Greilberger JF. Several indicators of oxidative stress, immunity, and illness improved in trained men consuming an encapsulated juice powder concentrate for 28 weeks. J Nutr 2007;137(12):2737-41.

8. Nantz MP, Rowe CA, Nieves C Jr, Percival SS. Immunity and antioxidant capacity in humans is enhanced by consumption of a dried, encapsulated fruit and vegetable juice concentrate. J Nutr 2006;136(10):2606-10.

9. Vereecken C, Pedersen TP, Ojala K, Krølner R, Dzielska A, Ahluwalia N, et al. Fruit and vegetable consumption trends among adolescents from 2002 to 2010 in 33 countries. Eur J Public Health 2015;25 Suppl 2:16-9.

10. Likus W, Milka D, Bajor G, Jachacz-Łopata M, Dorzak B. Dietary habits and physical activity in students from the Medical University of Silesia in Poland. Rocz Panstw Zakl Hig 2013;64(4):317-24.

11. Teleman AA, de Waure C, Soffiani V, Poscia A, Di Pietro ML. Nutritional habits in Italian university students. Ann Ist Super Sanita 2015;51(2):99-105.

12. Kołłajtis-Dołowy A, Boniecka I. Pro-health nutritional behaviors of selected group of students of the Medical University of Warsaw. Rocz Państw Zakł Hig 2007;58(1):273-8.

13. Garcia MC, Puchalska P, Esteve C, Marina ML. Vegetable foods: a cheap source of proteins and peptides with antihypertensive, antioxidant, and other less occurrence bioactivities. Talanta 2013;106:328-49.

14. Slavin JL, Lloyd B. Health benefits of fruits and vegetables. Adv Nutr 2012;3(4):506-16.

15. Liu RH. Health-promoting components of fruits and vegetables in the diet. Adv Nurt 2013;4(3):384-92.

16. Slavin JL. Carbohydrates, dietary fiber and resistant starch in white vegetables: links to health outcomes. Adv Nutr 2013:4(3):351-5.

17. Silveira JA, Taddei JA, Guerra PH, Nobre MR. Effectiveness of scholl-based nutrition education interventions to prevent and reduce excessive weight gain in children and adolescent: a systematic review. J Pediatr (Rio J) 2011;87(5):382-92. doi: 10.2223/JPED.2123

18. Vardanjani A, Reisi M, Javadzade H, Pour Z, Tavassoli E. The effect of nutrition education on knowledge, attitude, and performance about junk food consumption among students of female primary schools. J Educ Health Promot 2015;4:53.

19. James EL, Stacey FG, Chapman K, Boyes AW, Burrows T, Girgis A, et al. Impact of a nutrition and physical activity intervention (ENRICH: Excercise and Nutrition Routine Improving Cancer Health) on health behaviours of cancer survivors and carers: a pragmatic randomized controlled trial. BMC Cancer 2015;15:710.

20. Amini M, Djazayery A, Majdzadeh R, Taghdisi MH, Jazayeri S. Effect of school-based interventions to control childhood obesity: a review of reviews. Int J Prev Med 2015;3:6-68.

21. Florindo AA, Brownson RC, Mielke G, Gomes GA, Parra DC, Siqueira FV, et al. Association of knowledge, preventive counseling and personal health behaviors on physical activity and consumption of fruits or vegetables in community health workers. BMC Public Health 2015;15(1):344.

22. O kampanii. Pora na pomidora. http://www.poranapomidora.com/ o-kampanii (10.08.2016).

23. Shi Z, Zhang T, Byles J, Martin S., Avery JC, Taylor AW. Food habits, lifestyle factors and morality among oldest old Chinese: the Chinese longitudinal healthy longevity survey (CLHLS). Nutrients 2015;7(9):7562-79.

24. Pierce JP, Natarajan L, Caan BJ, Parker BA, Greenberg ER, Flatt SW, et al. Influence of a diet very high in vegetables, fruit and fiber and low in fat on prognosis following treatment for breast cancer: the Women's Healthy Eating and Living (WHEL) randomized trail. JAMA 2007;18(3):289-98.

25. Esfahani A, Wong JM, Truan J, Villa CR, Mirrahimi A, Srichaikul K, et al. Health effects of mixed fruit and vegetable concentrates: a systematic review of the clinical interventions. J Am Coll Nutr 2011;30(5):285-94.

26. Oyebode O, Gordon-Dseagu V, Walker A, Mindell JS. Fruit and vegetable consumption and all-cause, cancer and CVD mortality: analysis of Health Survey for England data. J Epidemiol Community Health 2014;68(9):856-62.

27. Bray GA. Fructose intake is a predictor of LDL particle size in overweight schoolchildren. Am J Clin Nutr 2007;86(4):895-6.

28. Platta A. Rola diety bogatoresztkowej w profilaktyce i leczeniu zaparć, otyłości, cukrzycy i chorób układu sercowo-naczyniowego. Zesz Nauk Morsk w Gdyni 2014;86:154-65. 